\title{
Prognostic significance of PDCD4 expression and association with microRNA-21 in each Dukes' stage of colorectal cancer patients
}

\author{
ATSUSHI HORIUCHI, HISAE IINUMA, TAKUYAAKAHANE, RYU SHIMADA and TOSHIAKI WATANABE \\ Department of Surgery, Teikyo University School of Medicine, Tokyo 173-0003, Japan
}

Received September 20, 2011; Accepted October 21, 2011

DOI: $10.3892 /$ or.2012.1648

\begin{abstract}
Down-regulation of the novel tumor suppressor gene programmed cell death 4 (PDCD4) was demonstrated in several types of cancer and regulation by micro-RNA is gaining attention. However, the clinical significance of the PDCD4 gene in colorectal cancer (CRC) patients still remains unclear. In particular, the significance of PDCD4 mRNA expression in each tumor stage has not been reported. In this study, we evaluated the prognostic value of PDCD4 expression in each Dukes' stage of CRC patients. Furthermore, relationships between the PDCD4 mRNA and microRNA-21 (miR-21) were evaluated. Tumor tissues and normal adjacent tumor tissues from 326 patients with CRC (Dukes' stage A, 44 cases; Dukes' B, 118 cases; Dukes' C, 100 cases; Dukes' D, 64 cases) were examined. The PDCD4 mRNA was investigated by the quantitative real-time RT-PCR method and miR-21 was examined by TaqMan microRNA assays. The overall survival rates (OS) and disease-free survival rates (DFS) of low PDCD4 patients were significantly worse than those of patients with high expression. In analysis of each tumor stage, OS and DFS of patients with low PDCD4 levels were significantly worse than those with high PDCD4 levels in Dukes' stage B and C. In Dukes' stage D, patients with low PDCD4 expression showed a significant worse OS compared to those of patients with high PDCD4 expression. In contrast, no significant differences were seen between these groups in patients with Dukes' stage A. PDCD4 expression in CRC tissues was an independent prognostic factor in Dukes' stage B, C and D. Significant inverse correlations were demonstrated between PDCD4 and miR-21. The reduced PDCD4 mRNA expression is associated with poor prognosis in CRC patients with Dukes' stage B, C and D.
\end{abstract}

Correspondence to: Dr Hisae Iinuma, Department of Surgery, Teikyo University School of Medicine, 2-11-1 Kaga, Itabashi-ku, Tokyo 173-0003, Japan

E-mail: iinuma@med.teikyo-u.ac.jp

Abbreviations: PDCD4, programmed cell death 4; RT-PCR, reverse transcription-polymerase chain reaction; $\mathrm{CRC}$, colorectal cancer

Key words: PDCD4 microRNA-21, prognostic factor, colorectal cancer
Furthermore, PDCD4 mRNA levels were negatively regulated by miR-21in each tumor stage of CRC.

\section{Introduction}

Programmed cell death 4 (PDCD4) has been characterized as a new tumor suppressor gene (1). PDCD4 was described by Colburn and her group (2) as a new tumor suppressor gene, its overexpression being sufficient to inhibit TPA-induced neoplastic transformation. It is known that PDCD4 plays a key role in suppressing tumor genesis by regulating several other genes involved in multiple processes, including apoptosis, cell cycle and cell proliferation (2). Molecules regulated by PDCD 4 induce p21, CDK4, ornithine decarboxylate, carbonic anhydrase II, JNK/c-Jun/AP-1 and the urokinase-receptor (u-PAR) gene (3-7). It is known that PDCD4 expression is downregulated in several human cancers. Analysis of protein and/ or mRNA levels in human tumor tissues of liver, lung, ovary, skin, brain and stomach revealed that PDCD4 expression in these tumor tissues is lower than those in adjacent normal tissues (8). Therefore, it is of interest to determine whether PDCD4 can be used as a prognostic marker to predict an individual patient's risk. However, to date only a few clinical studies have investigated the potential use of PDCD4 as a prognostic factor.

The potential of PDCD4 as a prognostic factor has been reported in lung and gastric cancer, and these studies suggest that a down-regulation of PDCD4 is associated with a poor prognosis $(9,10)$. In colorectal cancer $(\mathrm{CRC})$, only one study which examined the PDCD4 protein levels by immunohistochemistry has reported the prognostic value of PDCD4 (9). However, no report exists on the characteristics of PDCD4 mRNA in each tumor stage of CRC patients.

MicroRNAs (miRNAs) are a class of mature non-coding small 21-25 nucleotides that participate in the regulation of cell differentiation, cell cycle progression and apoptosis (11-13). The miRNAs target protein-coding mRNAs at the posttranscriptional level by direct cleavage of the mRNA or by inhibition of protein synthesis. Several studies have revealed that PDCD4 protein is negatively regulated by miR-21 in pancreatic, breast, gastric and coloractal cancer $(8,10,14-17)$. However, no previous report exists on the correlation between PDCD4 levels and miR-21 in each tumor stage of CRC patients.

In this study, we investigated the clinicopathological characteristics and prognostic value of PDCD4 mRNA in CRC 
A OS

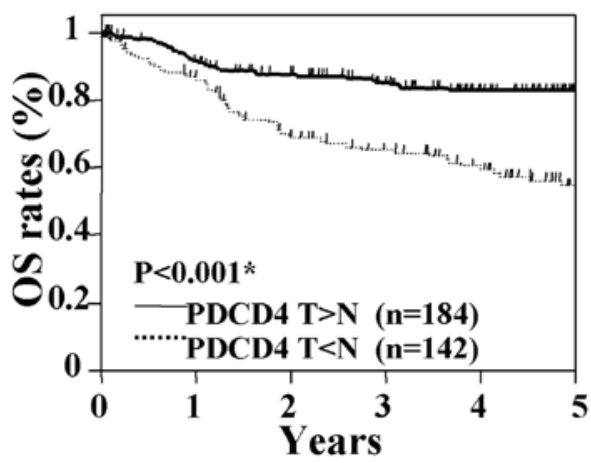

\section{B DFS}

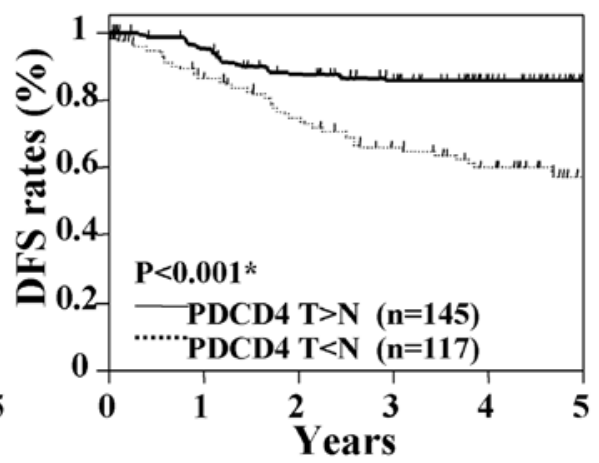

Figure 1. Kaplan-Meier survival curves of OS and DFS based on PDCD4 expression in all patients. The patients were divided into two groups: the low PDCD4 group $(\mathrm{T}<\mathrm{N})$ in which the expression levels of PDCD4 were lower in tumor than in non-tumor tissues and the high PDCD4 group (T $>\mathrm{N})$ in which the expression levels of PDCD4 were higher in tumor than non-tumor tissues. The significances of these groups for OS (A) and DFS (B) were analyzed. ${ }^{\mathrm{P}}<0.05$.

patients of each Dukes' stage, and we examined the association between the PDCD4 mRNA and miR-21 levels of CRC patients, in each tumor stage.

\section{Patients and methods}

Patients and tissue samples. A total of $326 \mathrm{CRC}$ patients were studies from May 2000 to April 2010 at Teikyo University Hospital (Tokyo). The median follow-up period was 45 months (range, 2-89 months). All samples were derived from patients who did not receive any radiotherapy or chemotherapy prior to surgery. Immediately following surgical resection, tumor and adjacent normal tissues were frozen in liquid nitrogen and stored until use. The study protocol conformed to the guidelines of the ethics committee. It was approved by the review board of Teikyo University and written informed consent was obtained from all patients.

Quantitative real-time RT-PCR for PDCD4 $m R N A$. Total RNAs were extracted by miRNeasy Mini Kit (Qiagen, Inc., Valencia, CA, USA) and complementary DNA (cDNA) synthesis was performed using random hexamer primers and SuperScript II reverse transcriptase according to the manufacturer's protocol (Invitrogen Corp., CA, USA). Quantitative real-time PCR amplification (qRT-PCR) of PDCD4 (NM 014456) and GAPDH mRNA (internal control) were measured using a LightCycler (Roche Applied Science, IN, USA). The amplifications of PDCD 4 mRNA were performed according to the previously described method using the FastStart DNA Master SYBR-Green I kit (Roche Diagnostics, Mannheim, Germany) (18). The PCR conditions of PDCD 4 mRNA were $95^{\circ} \mathrm{C}$ for $10 \mathrm{~min}$, followed by 35 cycles $95^{\circ} \mathrm{C}$ for $10 \mathrm{sec}, 65^{\circ} \mathrm{C}$ for $10 \mathrm{sec}$ and $72^{\circ} \mathrm{C}$ for $10 \mathrm{sec}$. The PCR products were then subjected to a temperature gradient from 68 to $95^{\circ} \mathrm{C}$ at $0.1 / \mathrm{sec}$, with continuous fluorescence monitoring to produce melting curves of the products. The expression levels of PDCD4 mRNA were normalized to GAPDH mRNA expression.

TaqMan microRNA assay for miR-21. Total RNAs, including the miRNAs were extracted from 326 primary CRC tissues and normal tissues by miRNeasy Mini Kit (Qiagen). The miR-21 and RNU6B-specific cDNA were synthesized using gene-specific primer sets according to the TaqMan microRNA assays protocol (Applied Biosystems, Inc., Foster City, CA, USA). RNU6B was used as internal control. In brief, reverse transcriptase reactions contained $10 \mathrm{ng}$ of total RNAs, $50 \mathrm{nmol} /$ stem-loop RT promer, 1X RT buffer, $0.25 \mathrm{mmol} / 1$ each of deoxynucleotide triphosphate (dNTP), $3.33 \mathrm{U} / \mu 1$ MultiScribe reverse transcriptase and $0.25 \mathrm{U} / \mu 1 \mathrm{RNase}$ inhibitor. The $7.5 \mu \mathrm{l}$ reaction samples were incubated in GeneAmp PCR System 9700 (Applied Biosystems, Inc.) for $30 \mathrm{~min}$ at $16^{\circ} \mathrm{C}, 30 \mathrm{~min}$ at $42^{\circ} \mathrm{C}, 5 \mathrm{~min}$ at $85^{\circ} \mathrm{C}$ and then folded at $4^{\circ} \mathrm{C}$. Quantitative real-time PCR was performed using ABI Step One (Applied Biosystems, Inc.). The $10 \mu \mathrm{l}$ PCR samples included $0.67 \mu \mathrm{l}$ of RT products, $1 \mathrm{X}$ TaqMan Universal PCR master mix and $1 \mu \mathrm{l}$ of primers and probe mix were incubated in 48-well optical plates. The PCR conditions were $95^{\circ} \mathrm{C}$ for $10 \mathrm{~min}$, followed by 40 cycles of $95^{\circ} \mathrm{C} 15 \mathrm{sec}$ and $60^{\circ} \mathrm{C}$ for $6 \mathrm{sec}$. Each sample was analyzed in duplicate. Relative quantification of miRNA expression was calculated using the $2^{-\Delta \Delta C T}$ method, where $\Delta \Delta \mathrm{CT}=\Delta \mathrm{CT}\left(\mathrm{C}_{\mathrm{T} \text { miR21 }}-\mathrm{C}_{\mathrm{T} \text { RNU6B }}\right)_{\text {tumor tissues }}-\Delta \mathrm{CT}\left(\mathrm{C}_{\mathrm{T} \text { miR21 }}-\right.$ $\left.\mathrm{C}_{\mathrm{T} \text { RNU6B }}\right)_{\text {normal tissues. }}$. The raw data are presented as the relative quantity of target miRNA, normalized with respect to RNU6B and relative to a calibrator sample.

Statistical analysis. The relationships were analyzed using the Student's t-test, the $\chi^{2}$ test and ANOVA. Overall survival (OS) and disease-free survival (DFS) curves were analyzed using the Kaplan-Meier method and the differences were examined using log-rank tests. Cox proportional-hazards regression analysis was used to estimate univariate and multivariate hazard ratios for OS and DFS. All P-values are two-sided, and $<0.05$ was considered statistically significant. Statistical analyses were performed using the JMP 7.0 software (SAS Institute, Inc., NC, USA).

\section{Results}

Correlation between PDCD4 mRNA levels and OS and DFS. This study included $326 \mathrm{CRC}$ patients (193 men and 133 women) with a mean age 69 years (range, 19-88 years). To 


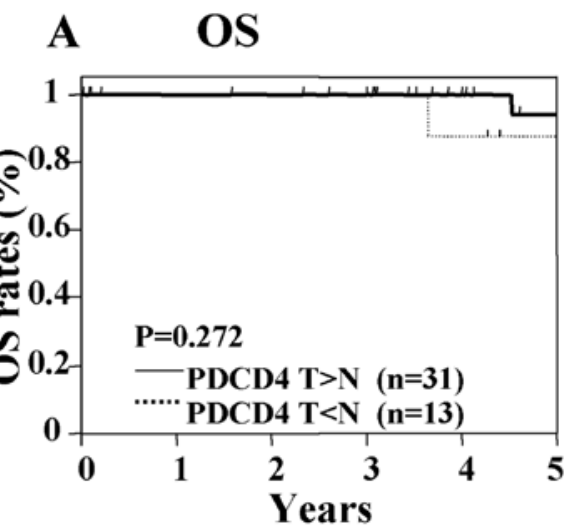

\section{B DFS}

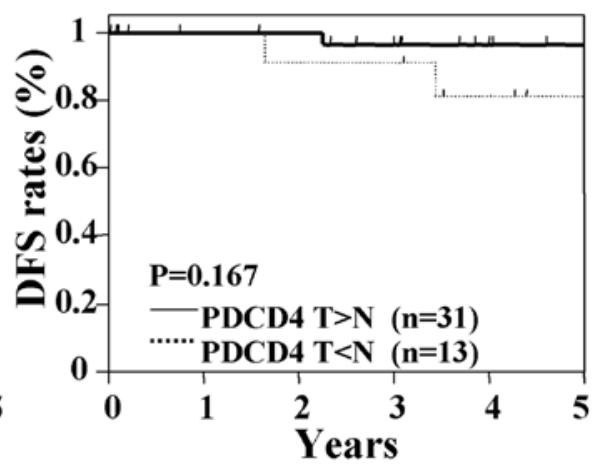

Figure 2. Kaplan-Meier survival curves of OS and DFS based on PDCD4 expression in Dukes' stage A patients. The patients were divided into two groups: the low PDCD4 group $(\mathrm{T}<\mathrm{N})$ and the high PDCD4 group $(\mathrm{T}>\mathrm{N})$ as described in Fig. 1. The significance of these groups for OS (A) and DFS (B) was analyzed.

A OS

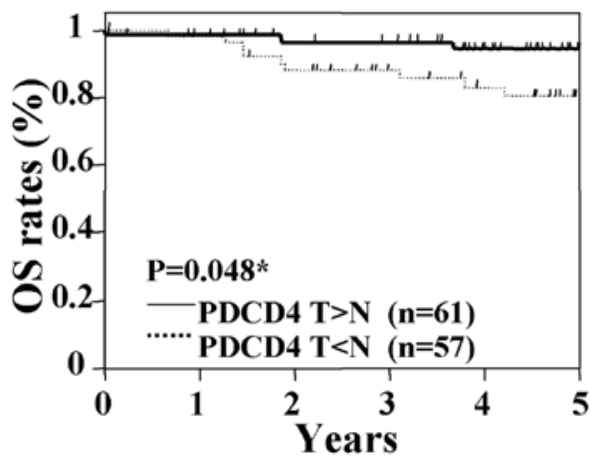

B DFS

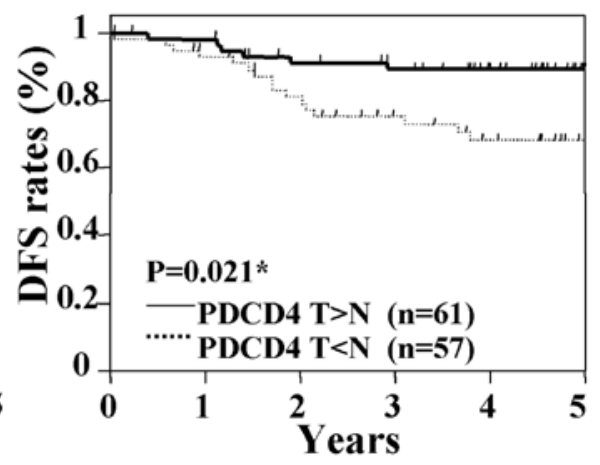

Figure 3. Kaplan-Meier survival curves of OS and DFS based on PDCD4 expression in Dukes' stage B patients. The patients were divided into two groups: the low PDCD4 group $(\mathrm{T}<\mathrm{N})$ and the high PDCD4 group $(\mathrm{T}>\mathrm{N})$ as described in Fig. 1. The significance of these groups for OS (A) and DFS (B) was analyzed. ${ }^{*} \mathrm{P}<0.05$.

evaluate the prognostic significance of PDCD4 mRNA levels in CRC, patients were divided into two groups. One group had lower expression levels of PDCD4 mRNA in tumor than nontumor tissues (low PDCD4 group) and the other group had higher expression levels in tumor than non-tumor tissues (high PDCD4 group).

Kaplan-Meier OS and DFS curves of the CRC patients according to the status of PDCD4 mRNA levels were examined in all patients (Fig. 1). The OS of patients in the low PDCD4 group showed significantly worse survival rates than those who were in the high PDCD4 group $(\mathrm{P}<0.001)$ (Fig. 1A). DFS analysis revealed that the patients in the low PDCD4 group had significantly worse survival rates than those who were in the high PDCD4 group $(\mathrm{P}<0.001)$ (Fig. 1B). Next, OS and DFS curves in each tumor stage were examined according to the PDCD4 levels. In patients with Dukes' stage A, significant differences of OS and DFS was not demonstrated between the low PDCD4 group and the high PDCD4 group (Fig. 2). In Dukes' stage B, OS and DFS of patients in the low PDCD4 group showed significantly worse survival rates than those in the high PDCD4 group (OS, $\mathrm{P}=0.048$; DFS, $\mathrm{P}=0.021$ ) (Fig. 3). In Dukes' stage $\mathrm{C}$, OS and DFS of patients in the low PDCD4 group showed signifi- cantly worse survival rates than those with high PDCD4 group (OS, $\mathrm{P}=0.001$; DFS, $\mathrm{P}=0.016$ ) (Fig. 4). In Dukes' stage $\mathrm{D}, \mathrm{OS}$ analysis revealed that the patients with low PDCD4 had significantly worse survival rates than those with high PDCD4 ( $\mathrm{P}=0.028)$ (Fig. 5). These results suggest that low expression of PDCD4 mRNA is associated with poor prognosis in CRC patients with Dukes' stage B, C and D.

Univariate and multivariate Cox analysis for OS and DFS. Table I shows the results of univariate and multivariate Cox proportional hazard regression analysis for OS in all of the CRC patients $(n=326)$. Multivariate analysis was performed for factors that showed significance in univariate analysis. In the univariate analysis, depth of invasion, lymph node metastasis, lymphatic invasion, venous invasion, histological type, liver metastasis, peritoneal dissemination, serum CEA, serum CA19-9, Dukes' stage and PDCD4 mRNA (PDCD4) level showed significance for OS. In the multivariate analysis, Dukes' stage and PDCD4 showed significance for OS. Table II shows the results of univariate and multivariate Cox analysis for DFS in CRC patients who had undergone curative surgery $(n=262)$. In the univariate analysis, depth of invasion, lymph node metastasis, lymphatic invasion, venous invasion, histo- 
Table I. Univariate and multivariate analysis of prognostic factors for OS of all patients.

\begin{tabular}{|c|c|c|c|c|c|c|}
\hline \multirow[b]{2}{*}{ Variables } & \multicolumn{3}{|c|}{ Univariate analysis } & \multicolumn{3}{|c|}{ Multivariate analysis } \\
\hline & $\begin{array}{l}\text { Regression } \\
\text { coefficient }\end{array}$ & $\begin{array}{c}\text { Hazard ratio } \\
(95 \% \mathrm{CI})\end{array}$ & P-value & $\begin{array}{l}\text { Regression } \\
\text { coefficient }\end{array}$ & $\begin{array}{c}\text { Hazard ratio } \\
(95 \% \mathrm{CI})\end{array}$ & P-value \\
\hline Tumor size & 0.422 & $\begin{array}{c}1.524 \\
(0.990-2.352)\end{array}$ & 0.056 & & - & \\
\hline Depth of invasion & 2.177 & $\begin{array}{c}8.823 \\
(1.961-155.540)\end{array}$ & $0.001^{\mathrm{a}}$ & 0.728 & $\begin{array}{c}2.070 \\
(0.404-38.043)\end{array}$ & 0.442 \\
\hline Lymph node metastasis & 1.346 & $\begin{array}{c}3.840 \\
(2.418-6.295)\end{array}$ & $<0.001^{\mathrm{a}}$ & -0.438 & $\begin{array}{c}0.645 \\
(0.253-1.792)\end{array}$ & 0.386 \\
\hline Lymphatic invasion & 1.177 & $\begin{array}{c}3.245 \\
(2.095-5.093)\end{array}$ & $<0.001^{\mathrm{a}}$ & 0.423 & $\begin{array}{c}1.526 \\
(0.877-2.686)\end{array}$ & 0.135 \\
\hline Venous invasion & 1.066 & $\begin{array}{c}2.905 \\
(1.761-5.046)\end{array}$ & $<0.001^{\mathrm{a}}$ & 0.445 & $\begin{array}{c}1.560 \\
(0.820-3.152)\end{array}$ & 0.180 \\
\hline Histological type & 0.784 & $\begin{array}{c}2.190 \\
(1.409-3.382)\end{array}$ & $0.001^{\mathrm{a}}$ & 0.188 & $\begin{array}{c}1.207 \\
(0.687-2.090)\end{array}$ & 0.508 \\
\hline Liver metastasis & 1.648 & $\begin{array}{c}5.199 \\
(3.107-8.431)\end{array}$ & $<0.001^{\mathrm{a}}$ & 0.303 & $\begin{array}{c}1.353 \\
(0.634-2.777)\end{array}$ & 0.424 \\
\hline Peritoneum dissemination & 2.130 & $\begin{array}{c}8.412 \\
(4.377-15.001)\end{array}$ & $<0.001^{\mathrm{a}}$ & 0.796 & $\begin{array}{c}2.216 \\
(0.860-5.231)\end{array}$ & 0.096 \\
\hline Serum CEA & 1.157 & $\begin{array}{c}3.179 \\
(1.959-5.340)\end{array}$ & $<0.001^{\mathrm{a}}$ & 0.568 & $\begin{array}{c}1.765 \\
(0.934-3.399)\end{array}$ & 0.080 \\
\hline Serum CA19-9 & 0.921 & $\begin{array}{c}2.513 \\
(1.517-4.121)\end{array}$ & $0.004^{\mathrm{a}}$ & 0.177 & $\begin{array}{c}1.194 \\
(0.625-2.260)\end{array}$ & 0.588 \\
\hline Dukes' stage & 1.908 & $\begin{array}{c}6.741 \\
(3.911-12.496)\end{array}$ & $<0.001^{\mathrm{a}}$ & 1.753 & $\begin{array}{c}5.770 \\
(1.769-18.331)\end{array}$ & $0.004^{\mathrm{a}}$ \\
\hline PDCD4 & 1.045 & $\begin{array}{c}2.843 \\
(1.820-4.543)\end{array}$ & $<0.001^{\mathrm{a}}$ & 1.169 & $\begin{array}{c}3.217 \\
(1.840-5.857)\end{array}$ & $<0.001^{\mathrm{a}}$ \\
\hline
\end{tabular}

${ }^{\mathrm{a}} \mathrm{P}<0.05$.

A OS

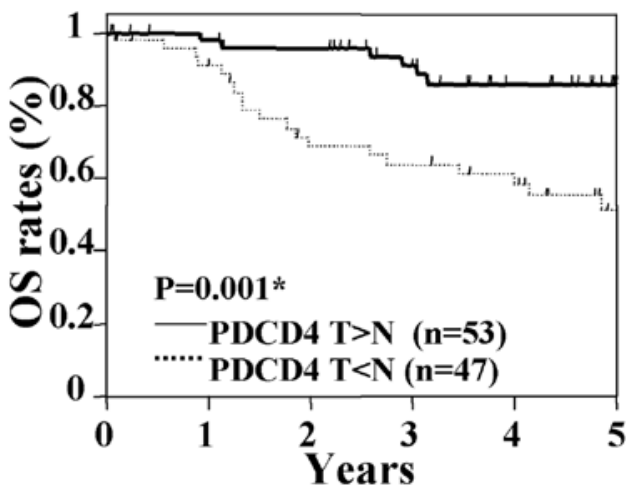

B DFS

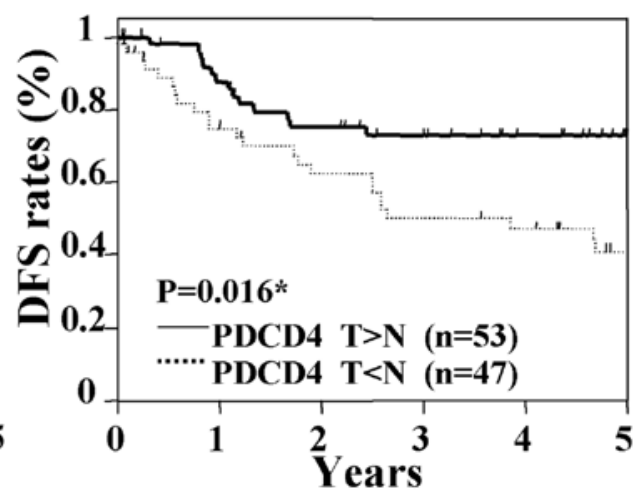

Figure 4. Kaplan-Meier survival curves of OS and DFS based on PDCD4 expression in Dukes' stage C patients. The patients were divided into two groups: the low PDCD4 group $(\mathrm{T}<\mathrm{N})$ and the high PDCD4 group $(\mathrm{T}>\mathrm{N})$ as described in Fig. 1. The significance of these groups for OS (A) and DFS (B) was analyzed. ${ }^{*} \mathrm{P}<0.05$.

logical type, serum CEA, serum CA19-9, Dukes' stage and PDCD4 showed significance for DFS. In the multivariate analysis, venous invasion, serum CEA, Dukes' stage and PDCD4 showed significance for DFS. 
Table II. Univariate and multivariate analysis of prognostic factors for DFS of patients who had undergone curative surgery.

\begin{tabular}{|c|c|c|c|c|c|c|}
\hline \multirow[b]{2}{*}{ Variables } & \multicolumn{3}{|c|}{ Univariate analysis } & \multicolumn{3}{|c|}{ Multivariate analysis } \\
\hline & $\begin{array}{l}\text { Regression } \\
\text { coefficient }\end{array}$ & $\begin{array}{l}\text { Hazard ratio } \\
(95 \% \mathrm{CI})\end{array}$ & P-value & $\begin{array}{l}\text { Regression } \\
\text { coefficient }\end{array}$ & $\begin{array}{c}\text { Hazard ratio } \\
(95 \% \mathrm{CI})\end{array}$ & P-value \\
\hline Tumor size & 0.069 & $\begin{array}{c}1.071 \\
(0.639-1.764)\end{array}$ & 0.791 & & - & \\
\hline Depth of invasion & 1.298 & $\begin{array}{c}3.660 \\
(1.145-22.320)\end{array}$ & $0.025^{\mathrm{a}}$ & 0.138 & $\begin{array}{c}1.148 \\
(0.320-7.357)\end{array}$ & 0.854 \\
\hline Lymph node metastasis & 1.050 & $\begin{array}{c}2.858 \\
(1.737-4.771)\end{array}$ & $<0.001^{\mathrm{a}}$ & & - & \\
\hline Lymphatic invasion & 0.837 & $\begin{array}{c}2.310 \\
(1.401-3.795)\end{array}$ & $0.001^{\mathrm{a}}$ & -0.021 & $\begin{array}{c}0.980 \\
(0.516-1.848)\end{array}$ & 0.949 \\
\hline Venous invasion & 0.748 & $\begin{array}{c}2.112 \\
(1.259-3.666)\end{array}$ & $0.004^{\mathrm{a}}$ & 0.627 & $\begin{array}{c}1.871 \\
(1.019-3.590)\end{array}$ & $0.043^{\mathrm{a}}$ \\
\hline Histological type & 0.549 & $\begin{array}{c}1.732 \\
(1.021-2.869)\end{array}$ & $0.042^{\mathrm{a}}$ & 0.271 & $\begin{array}{c}1.312 \\
(0.688-2.434)\end{array}$ & 0.402 \\
\hline Serum CEA & 0.972 & $\begin{array}{c}2.643 \\
(1.570-4.538)\end{array}$ & $0.003^{\mathrm{a}}$ & 0.758 & $\begin{array}{c}2.133 \\
(1.163-3.973)\end{array}$ & $0.014^{\mathrm{a}}$ \\
\hline Serum CA19-9 & 0.903 & $\begin{array}{c}2.467 \\
(1.383-4.265)\end{array}$ & $0.003^{\mathrm{a}}$ & 0.312 & $\begin{array}{c}1.366 \\
(0.718-2.552)\end{array}$ & 0.336 \\
\hline Dukes' stage & 1.050 & $\begin{array}{c}2.858 \\
(1.737-4.771)\end{array}$ & $<0.001^{\mathrm{a}}$ & 1.008 & $\begin{array}{c}2.739 \\
(1.519-5.106)\end{array}$ & $0.001^{\mathrm{a}}$ \\
\hline PDCD4 & 1.104 & $\begin{array}{c}3.018 \\
(1.800-5.236)\end{array}$ & $<0.001^{\mathrm{a}}$ & 0.935 & $\begin{array}{c}2.547 \\
(1.436-4.695)\end{array}$ & $0.001^{\mathrm{a}}$ \\
\hline
\end{tabular}

${ }^{\mathrm{a}} \mathrm{P}<0.05$.

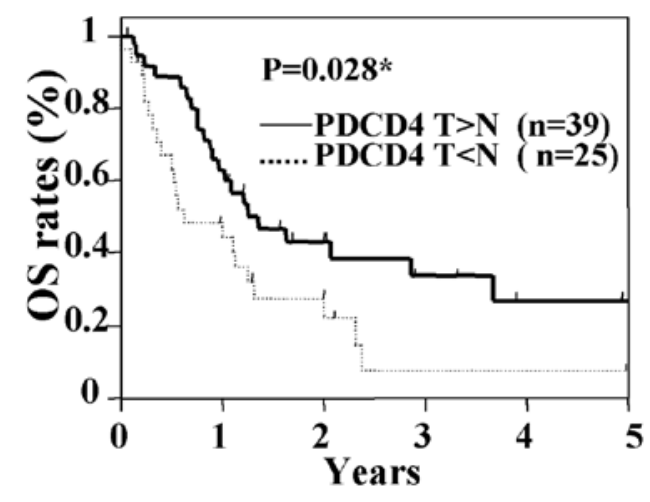

Figure 5. Kaplan-Meier survival curves of OS based on PDCD4 expression in Dukes' stage D patients. The patients were divided into two groups: the low PDCD4 group $(\mathrm{T}<\mathrm{N})$ and the high PDCD4 group $(\mathrm{T}>\mathrm{N})$ as described in Fig. 1. The significance of these groups for OS was analyzed. ${ }^{*} \mathrm{P}<0.05$.

We examined the univariate and multivariate Cox analysis in patients with Dukes' stage B, C and D, respectively. In the univariate analysis of Dukes' stage B patients, serum CEA and PDCD4 showed significance for OS and DFS (Table III). In multivariate analysis, only PDCD4 showed significance for OS and DFS. In the univariate analysis of Dukes' stage $\mathrm{C}$ patients, serum CEA, serum CA19-9 and PDCD4 showed significance for OS and DFS (Table IV). In multivariate analysis, only PDCD4 showed significance for OS and DFS. Table V shows the Cox analysis in patients with Dukes' stage D. In univariate analysis, histological type, liver metastasis and PDCD4 show significance for OS. Liver metastasis and PDCD4 show significance for OS in multivariate analysis. These results suggest that PDCD4 mRNA levels of tumor tissues have an independent prognostic value for OS and DFS in CRC patients with Dukes' stage B, C and D.

Correlation of PDCD4 $\mathrm{mRNA}$ and miR-21 expressions. The correlation between PDCD4 mRNA and miR-21 expression of CRC samples was analyzed in each tumor stage (Fig. 6). Significant inverse correlations were shown between PDCD4 mRNA and miR-21 in Dukes' stage A $(\gamma=-0.524, \mathrm{P}=0.001), \mathrm{B}$ $(\gamma=-0.509, P=0.003), C(\gamma=-0.472, P=0.009)$ and $D(\gamma=-0.492$, $\mathrm{P}=0.005)$.

\section{Discussion}

In this study, we examined the prognostic value of the tumor suppressor gene PDCD4 in CRC patients. Our results demonstrated that the low expression of PDCD4 mRNA in CRC tissue showed a significant poor prognosis for OS and DFS in CRC patients with Dukes' stage B, C and D. Furthermore, the expression of PDCD4 mRNA of CRC tissues showed a 
Table III. Univariate and multivariate analysis of prognostic factors for OS and DFS in Dukes' stage B patients.

\begin{tabular}{|c|c|c|c|c|c|c|}
\hline \multirow[b]{2}{*}{ Variables } & \multicolumn{3}{|c|}{ Univariate analysis } & \multicolumn{3}{|c|}{ Multivariate analysis } \\
\hline & $\begin{array}{l}\text { Regression } \\
\text { coefficient }\end{array}$ & $\begin{array}{l}\text { Hazard ratio } \\
(95 \% \mathrm{CI})\end{array}$ & P-value & $\begin{array}{l}\text { Regression } \\
\text { coefficient }\end{array}$ & $\begin{array}{l}\text { Hazard ratio } \\
(95 \% \mathrm{CI})\end{array}$ & P-value \\
\hline \multicolumn{7}{|l|}{ OS } \\
\hline Tumor size & -0.139 & $\begin{array}{c}0.870 \\
(0.257-2.726)\end{array}$ & 0.811 & & - & \\
\hline Lymphatic invasion & 0.858 & $\begin{array}{c}2.358 \\
(0.695-7.425)\end{array}$ & 0.160 & & - & \\
\hline Venous invasion & 0.796 & $\begin{array}{c}2.217 \\
(0.661-9.991)\end{array}$ & 0.206 & & - & \\
\hline Histological type & 0.095 & $\begin{array}{c}1.100 \\
(0.244-3.689)\end{array}$ & 0.888 & & - & \\
\hline Serum CEA & 1.201 & $\begin{array}{c}3.325 \\
(1.043-12.499)\end{array}$ & $0.042^{\mathrm{a}}$ & 0.445 & $\begin{array}{c}1.560 \\
(0.467-5.442)\end{array}$ & 0.464 \\
\hline Serum CA19 & 1.221 & $\begin{array}{c}3.391 \\
(0.865-11.903)\end{array}$ & 0.077 & & - & \\
\hline PDCD4 & 1.611 & $\begin{array}{c}2.833 \\
(1.147-7.132)\end{array}$ & $<0.001^{\mathrm{a}}$ & 1.635 & $\begin{array}{c}3.421 \\
(1.215-9.302)\end{array}$ & $<0.001^{\mathrm{a}}$ \\
\hline \multicolumn{7}{|l|}{ DFS } \\
\hline Tumor size & -0.267 & $\begin{array}{c}0.766 \\
(0.319-1.746)\end{array}$ & 0.529 & & - & \\
\hline Lymphatic invasion & 0.538 & $\begin{array}{c}1.713 \\
(0.689-3.946)\end{array}$ & 0.234 & & - & \\
\hline Venous invasion & 0.147 & $\begin{array}{c}1.158 \\
(0.508-2.782)\end{array}$ & 0.730 & & - & \\
\hline Histological type & 0.587 & $\begin{array}{c}1.799 \\
(0.724-4.144)\end{array}$ & 0.195 & & - & \\
\hline Serum CEA & 0.985 & $\begin{array}{c}2.678 \\
(1.100-6.888)\end{array}$ & $0.030^{\mathrm{a}}$ & 0.864 & $\begin{array}{c}2.372 \\
(0.968-6.139)\end{array}$ & 0.059 \\
\hline Serum CA19 & 0.300 & $\begin{array}{c}1.350 \\
(0.383-3.767)\end{array}$ & 0.607 & & - & \\
\hline PDCD4 & 0.981 & $\begin{array}{c}2.667 \\
(1.137-6.942)\end{array}$ & $0.023^{\mathrm{a}}$ & 1.207 & $\begin{array}{c}3.344 \\
(1.285-10.336)\end{array}$ & $0.012^{\mathrm{a}}$ \\
\hline
\end{tabular}

${ }^{\text {a }} \mathrm{P}<0.05$.

significant negative correlation between the miR-21 levels in each tumor stage.

PDCD4 has been identified as a suppressor of transformation, tumorgenesis, progression, invasion, matrix-metalloproteinase activation and tumor growth and as an inducer of apoptosis (1-3). Furthermore, it has been demonstrated that PDCD4 suppresses the invasion- and progression-related molecular u-PAR at the transcriptional level and inhibits the metastatic process of cultured colon cancer $(19,20)$. The potential values of PDCD4 as prognostic biomarkers are of interest. To date, only a few clinical studies have investigated the potential of PDCD4 as a prognostic factor. In these studies, PDCD4 was examined by immunohistochemistry (21). An initial study by Göke et al reported a loss of nuclear PDCD4-staning in 6 out of 7 colon carcinoma (22).
A previous prognostic study on PDCD4 was performed in lung cancer patients, in whom the loss of PDCD4 protein was associated with poor survival in the univariate Kaplan-Meier analysis (9). In this study, OS was shown to be significant, but the potential impact of PDCD4 on DFS was not described. Moreover, multivariate analysis in these lung cancer patients was not examined. According to the CRC, there is only one study that identifies the prognostic value of PDCD4 protein by immunohistochemical procedure (8). Using Kaplan-Meier method and multivariate analysis on the CRC samples, it was demonstrated that PDCD4 protein level is independent prognostic factor of CRC patients. However, the prognostic impact of PDCD4 mRNA in CRC patients has not been reported. Furthermore, the characteristics of PDCD4 mRNA expression in each Dukes' stage cancer has not been reported. 
Table IV. Univariate and multivariate analysis of prognostic factors for OS and DFS in Dukes' stage C patients.

\begin{tabular}{|c|c|c|c|c|c|c|}
\hline \multirow[b]{2}{*}{ Variables } & \multicolumn{3}{|c|}{ Univariate analysis } & \multicolumn{3}{|c|}{ Multivariate analysis } \\
\hline & $\begin{array}{l}\text { Regression } \\
\text { coefficient }\end{array}$ & $\begin{array}{l}\text { Hazard ratio } \\
(95 \% \mathrm{CI})\end{array}$ & P-value & $\begin{array}{l}\text { Regression } \\
\text { coefficient }\end{array}$ & $\begin{array}{l}\text { Hazard ratio } \\
(95 \% \mathrm{CI})\end{array}$ & P-value \\
\hline \multicolumn{7}{|l|}{ OS } \\
\hline Tumor size & -0.563 & $\begin{array}{c}0.570 \\
(0.232-1.281)\end{array}$ & 0.177 & & - & \\
\hline Lymphatic invasion & 0.760 & $\begin{array}{c}2.138 \\
(0.959-5.071)\end{array}$ & 0.063 & & - & \\
\hline Venous invasion & 0.334 & $\begin{array}{c}1.397 \\
(0.621-3.426)\end{array}$ & 0.427 & & - & \\
\hline Histological type & 0.0433 & $\begin{array}{c}1.044 \\
(0.425-2.353)\end{array}$ & 0.920 & & - & \\
\hline Serum CEA & 0.815 & $\begin{array}{c}2.258 \\
(1.001-5.395)\end{array}$ & $0.050^{\mathrm{a}}$ & 0.715 & $\begin{array}{c}2.043 \\
(0.726-5.618)\end{array}$ & 0.172 \\
\hline Serum CA19 & 0.866 & $\begin{array}{c}2.377 \\
(1.040-5.339)\end{array}$ & $0.041^{\mathrm{a}}$ & -0.219 & $\begin{array}{c}0.804 \\
(0.256-2.378)\end{array}$ & 0.695 \\
\hline PDCD4 & 1.446 & $\begin{array}{c}4.247 \\
(1.794-11.666)\end{array}$ & $0.001^{\mathrm{a}}$ & 1.180 & $\begin{array}{c}3.253 \\
(1.298-9.223)\end{array}$ & $0.011^{\mathrm{a}}$ \\
\hline \multicolumn{7}{|l|}{ DFS } \\
\hline Tumor size & -0.036 & $\begin{array}{c}0.964 \\
(0.495-1.842)\end{array}$ & 0.913 & & - & \\
\hline Lymphatic invasion & 0.499 & $\begin{array}{c}1.646 \\
(0.860-3.241)\end{array}$ & 0.133 & & - & \\
\hline Venous invasion & 0.781 & $\begin{array}{c}2.183 \\
(1.070-4.908)\end{array}$ & $0.031^{\mathrm{a}}$ & 0.888 & $\begin{array}{c}2.431 \\
(1.150-5.753)\end{array}$ & $0.019^{\mathrm{a}}$ \\
\hline Histological type & 0.134 & $\begin{array}{c}1.144 \\
(0.565-2.213)\end{array}$ & 0.699 & & - & \\
\hline Serum CEA & 0.887 & $\begin{array}{c}2.429 \\
(1.237-4.964)\end{array}$ & $0.010^{\mathrm{a}}$ & 0.572 & $\begin{array}{c}1.772 \\
(0.802-3.980)\end{array}$ & 0.157 \\
\hline Serum CA19 & 1.046 & $\begin{array}{c}2.845 \\
(1.452-5.552)\end{array}$ & $0.003^{\mathrm{a}}$ & 0.683 & $\begin{array}{c}1.979 \\
(0.918-4.338)\end{array}$ & 0.082 \\
\hline PDCD4 & 0.877 & $\begin{array}{c}2.403 \\
(1.243-4.861)\end{array}$ & $0.009^{\mathrm{a}}$ & 0.740 & $\begin{array}{c}2.096 \\
(1.057-4.373)\end{array}$ & $0.034^{\mathrm{a}}$ \\
\hline
\end{tabular}

${ }^{\mathrm{a}} \mathrm{P}<0.05$.

In this study, the prognostic significance of PDCD4 mRNA levels was investigated using the Kaplan-Meier method and Cox multivariate analysis on 326 patients with CRC in each Dukes' stage. Our data demonstrated the existence of an independent prognostic impact of PDCD4 mRNA for OS and DFS in CRC patients with Dukes' stage, B, C or D. In contrast, PDCD4 did not show significance for OS and DFS in the patients with Dukes' stage A cancer, possibly due to the small number of patients with recurrence and death. To the best of our knowledge, this is the first study to clarify the significant prognostic value of PDCD4 mRNA in each stage of CRC patients.

It is known that microRNAs target protein-coding mRNAs at the post-transcriptional level by direct cleavage of the mRNA or by inhibition of protein synthesis $(11,12,23)$. MiR-21 is one of the most prominent miRNAs implicated in the genesis and progression of several human cancers (24). Not only has it been implicated in the promotion of tumor growth, proliferation and response to chemotherapy, but also diverse studies have shown that miR-21 is overexpressed in several human malignant solid cancers such as glioblastoma, hepatocellular cancer, pancreatic cancer and CRC (16,17,25-29). Several studies have revealed that PDCD4 is negatively regulated by miR-21 in pancreatic cancer, breast cancer and gastric cancer $(10,14,16,17)$. In 156 CRC patients, we previously reported the significant inverse relationship between the PDCD4 and miR-21 expression (19). In the present study, we validated the relationship of PDCD4 mRNA and miR-21 in 362 CRC patients, and demonstrated a significant inverse relationship between PDCD4 mRNA and miR-21. Furthermore, we analyzed each Dukes' stage and 
Table V. Univariate and multivariate analysis of prognostic factors for OS in Dukes' stage D patients.

\begin{tabular}{|c|c|c|c|c|c|c|}
\hline \multirow[b]{2}{*}{ Variables } & \multicolumn{3}{|c|}{ Univariate analysis } & \multicolumn{3}{|c|}{ Multivariate analysis } \\
\hline & $\begin{array}{l}\text { Regression } \\
\text { coefficient }\end{array}$ & $\begin{array}{l}\text { Hazard ratio } \\
\quad(95 \% \mathrm{CI})\end{array}$ & P-value & $\begin{array}{l}\text { Regression } \\
\text { coefficient }\end{array}$ & $\begin{array}{l}\text { Hazard ratio } \\
\quad(95 \% \mathrm{CI})\end{array}$ & P-value \\
\hline Tumor size & 0.203 & $\begin{array}{c}1.225 \\
(0.658-2.391)\end{array}$ & 0.530 & & - & \\
\hline Lymph node metastasis & 0.520 & $\begin{array}{c}1.681 \\
(0.830-3.782)\end{array}$ & 0.155 & & - & \\
\hline Lymphatic invasion & 0.486 & $\begin{array}{c}1.625 \\
(0.872-3.177)\end{array}$ & 0.128 & & - & \\
\hline Venous invasion & 0.121 & $\begin{array}{c}1.128 \\
(0.512-2.978)\end{array}$ & 0.782 & & - & \\
\hline Histological type & 0.624 & $\begin{array}{c}1.867 \\
(1.019-3.488)\end{array}$ & $0.043^{\mathrm{a}}$ & 0.426 & $\begin{array}{c}1.532 \\
(0.803-2.970)\end{array}$ & 0.196 \\
\hline Liver metastasis & -0.646 & $\begin{array}{c}0.524 \\
(0.288-0.957)\end{array}$ & $0.036^{\mathrm{a}}$ & -0.614 & $\begin{array}{c}0.541 \\
(0.294-0.998)\end{array}$ & $0.049^{\mathrm{a}}$ \\
\hline Peritoneum dissemination & 0.483 & $\begin{array}{c}1.620 \\
(0.815-3.044)\end{array}$ & 0.162 & & - & \\
\hline Serum CEA & -0.320 & $\begin{array}{c}0.726 \\
(0.322-1.947)\end{array}$ & 0.494 & & - & \\
\hline Serum CA19-9 & -0.396 & $\begin{array}{c}0.673 \\
(0.325-1.393)\end{array}$ & 0.282 & & - & \\
\hline PDCD4 & 0.810 & $\begin{array}{c}2.248 \\
(1.217-4.180)\end{array}$ & $0.010^{\mathrm{a}}$ & 0.670 & $\begin{array}{c}1.955 \\
(1.015-3.785)\end{array}$ & $0.045^{\mathrm{a}}$ \\
\hline
\end{tabular}

${ }^{\mathrm{a}} \mathrm{P}<0.05$.

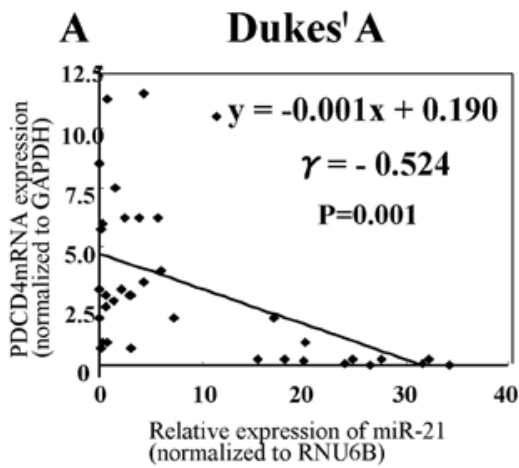

C Dukes'C

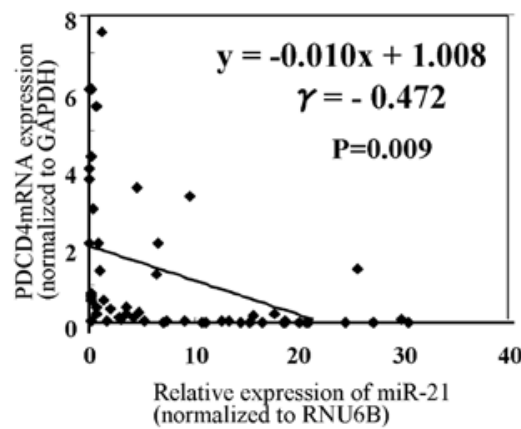

B Dukes' B

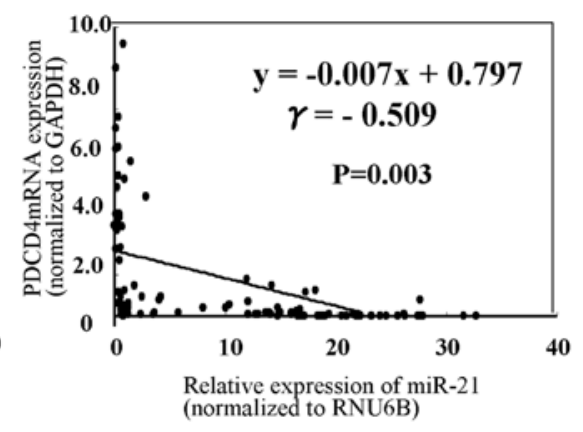

D

Dukes' D

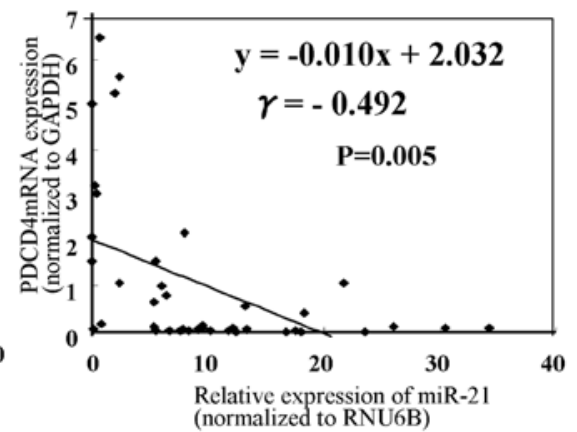

Figure 6. Correlation between the PDCD4 expression and miR-21 in each Dukes' stage. The correlation between the expressions of PDCD4 and miR-21 was examined. A significant inverse correlation was demonstrated between the PDCD4 and miR-21 expressions in Dukes' stage A (A), B (B), C (C) and D (D). 
demonstrated that these reverse correlations can be observed at each stage (Dukes' stage A, B, C and D). To the best of our knowledge, ours is the first report showing a significant correlation between miR-21 and PDCD4 mRNA expression levels in each stage of CRC clinical samples.

In conclusion, our study demonstrates that reduced PDCD4 mRNA of CRC tissues show a prognostic significance in all stages of CRC patients and these PDCD4 mRNA levels inversely correlate with miR-21 expressions. These molecules may have potential as a novel target with meaningful therapeutic applications.

\section{Acknowledgements}

We thank Miss. J. Tamura for her excellent technical assistance, and all members of colorectal group for support. This study was supported by a Grant-in-Aid for Scientific Research (C) (21591734).

\section{References}

1. Shibahara K, Asano M, Ishida Y, Aoki T, Koike T and Honjo T: Isolation of a novel mouse gene MA-3 that is induced upon programmed cell death. Gene 166: 297-301, 1995.

2. Cmarik JL, Min H, Hegamyer G, et al: Differentially expressed protein Pdcd4 inhibits tumor promoter-induced neoplastic transformation. Proc Natl Acad Sci USA 96: 14037-14042, 1999.

3. Leupold JH, Yang HS, Colburn NH, Asangani I, Post S and Allgayer H: Tumor suppressor Pdcd4 inhibits invasion/intravasation and regulates urokinase-receptor (u-PAR) gene expression via Sp-transcription factors. Oncogene 26: 4550-4562, 2007.

4. Yang H, Jansen A, Nair R, Shibahara K, Verma AK and Cmarik JL: A novel transformation suppressor, Pdcd4, inhibits AP-1 transactivation but not NF- $\kappa$ B or ODC transactivation. Oncogene 20: 669-676, 2001.

5. Bitomsky N, Bohm M and Klempnauer KH: Transformation suppressor protein Pdcd4 interferes with JNK-mediated phosphorylation of c-Jun and recruitment of the coactivator $\mathrm{p} 300$ by c-Jun. Oncogene 23: 7484-7493, 2004.

6. Palamarchuk A, Efanov A, Maximov V, Aqeilan RI, Croce CM and Pekarsky Y: Akt phosphorylates and regulates Pdcd4 tumor suppressor protein. Cancer Res 65: 11282-11286, 2005.

7. Ossowski L, Clunie G, Masucci MT and Blasi F: In vivo paracrine interaction between urokinase and its receptor: effect on tumor cell invasion. J Cell Biol 115: 1107-1112, 1991.

8. Mudduluru G, Medved F, Grobholz R, et al: Loss of programmed cell death 4 expression marks adenoma-carcinoma transition, correlates inversely with phosphorylated protein kinase B, and is an independent prognostic factor in resected colorectal cancer. Cancer 110: 1697-1707, 2007.

9. Chen Y,Knosel T, Kristiansen G, et al: Loss of PDCD4 expression in human lung cancer correlates with tumour progression and prognosis. J Pathol 200: 640-646, 2003.

10. Motoyama K, Inoue H, Mimori K, et al: Clinicopathological and prognostic significance of PDCD4 and microRNA-21 in human gastriccancer. Int J Oncol 36: 1089-1095, 2010.
11. Caldas C and Brenton JD: Sizing up miRNAs as cancer genes. Nat Med 11: 712-714, 2005.

12. Esquela-Kerscher A and Slack FJ: Oncomirs-microRNAs with a role in cancer. Nat Rev Cancer 6: 259-269, 2006.

13. Jovanovic $M$ and Hengartner MO: miRNAs and apoptosis: RNAs to die for. Oncogene 25: 6176-6187, 2006.

14. Iorio MV, Ferracin M, Liu CG, et al: MicroRNA gene expression deregulation in human breast cancer. Cancer Res 65: 7065-7070, 2005.

15. Frankel LB, Christoffersen NR, Jacobsen A, Lindow M, Krogh A and Lund AH: Programmed cell death 4 (PDCD4) is an important functional target of the microRNA miR-21 in breast cancer cells. J Biol Chem 283: 1026-1033, 2008.

16. Ma G, Guo KJ, Zhang H, et al: Expression of programmed cell death 4 and its clinicopathological significance in human pancreatic cancer. Zhongguo Yi Xue Ke Xue Yuan Xue Bao 27: 597-600, 2005.

17. Roldo C, Missiaglia E, Hagan JP, et al: MicroRNA expression abnormalities in pancreatic endocrine and acinar tumors are associated with distinctive pathologic features and clinical behavior. J Clin Oncol 24: 4677-4684, 2006.

18. Shibuya $H$, Iinuma $H$, Shimada $R$, Horiuchi $A$ and Watanabe $T$ : Clinicopathological and prognostic value of microRNA-21 and microRNA-155 in cololectal cancer. Oncology 79: 313-320, 2010.

19. Allgayer $\mathrm{H}$ : Molecular regulation of an invasion-related molecule-options for tumor staging and clinical strategies. Eur J Cancer 42: 811-819, 2006.

20. Yang HS, Matthews CP, Clair T, et al: Tumorigenesis suppressor Pdcd4 down-regulates mitogen-activated protein kinase kinase kinase kinase 1 expression to suppress colon carcinoma cell invasion. Mol Cell Biol 26: 1297-1306, 2006.

21. Lu Z, Liu M, Stribinskis V, et al: MicroRNA-21 promotes cell transformation by targeting the programmed cell death 4 gene. Oncogene 27: 4373-4379, 2008.

22. Göke R, Barth P, Schmidt A, Samans B and Lankat-Buttgereut B: Programmed cell death protein 4 suppresses CDK1/cdc2 via induction of p21(Waf1/Cip1). Am J Physiol Cell Physiol 287: 1541-1546, 2004.

23. Kloosterman WP and Plasterk RH: The diverse functions of microRNAs in animal development and disease. Dev Cell 11: 441-450, 2006.

24. Asangani IA, Rasheed SA, Nikolova DA, et al: MicroRNA-21 (mir-21) post-transcriptionally downregulates tumor suppressor Pdcd 4 and stimulates invasion, intravasation and metastasis in colorectal cancer. Oncogene 27: 2128-2136, 2008.

25. Chan JA, Krichevsky AM and Kosik KS: MicroRNA-21 is an antiapoptotic factor in human glioblastoma cells. Cancer Res 65: 6029-6033, 2005.

26. Gao F, Zhang P, Zhou C, et al: Frequent loss of PDCD4 expression in human glioma: possible role in the tumorigenesis of glioma. Oncol Rep 17: 123-128, 2007.

27. Chen Y, Liu W, Chao T, et al: MicroRNA-21 down-regulates the expression of tumor suppressor PDCD4 in human glioblastoma cell T98G. Cancer Lett 272: 197-205, 2008.

28. Zhang S, Li J, Jiang Y, Xu Y and Oin C: Programed cell death 4 (Pdcd4) suppresses metastatic potential of human hepatocellular carcinoma cells. J Exp Clin Cancer Res 28: 71, 2009. doi: 10.1186/1756-9966-28-71.

29. Chang KH, Miller N, Kheirelseid EAH, et al: MicroRNA-21 and PDCD4 expression in colorectal cancer. EJSO 37: 597-603, 2011. 